\title{
Prevalence of Mutans Streptococci Isolated from Complete Dentures and Their Susceptibility to Mouthrinses
}

\author{
Rodrigo Fernando Gonçalves ANDRÉ 1 \\ Ingrid Machado de ANDRADE ${ }^{1}$ \\ Cláudia Helena SILVA-LOVATO ${ }^{1}$ \\ Helena de Freitas Oliveira PARANHOS ${ }^{1}$ \\ Fabiana Cristina PIMENTA ${ }^{2}$ \\ Izabel Yoko $\mathrm{ITO}^{3}$ (in memoriam)
}

\author{
${ }^{1}$ Department of Dental Materials and Prosthodontics, Ribeirão Preto Dental School, \\ USP - University of São Paulo, Ribeirão Preto, SP, Brazil \\ ${ }^{2}$ Institute of Tropical Pathology and Public Health, UFG - Federal University of Goiás, Goiania, GO, Brazil \\ ${ }^{3}$ Department of Clinical, Toxicological and Bromatological Analyses, FCFRP - School of Pharmaceutical Sciences \\ of Ribeirão Preto, University of São Paulo, Ribeirão Preto, SP, Brazil
}

\begin{abstract}
The aims of this study were to evaluate the incidence of mutans streptococci (MS - sessile form) on complete maxillary dentures after use of a specific denture paste, and to determine the minimum inhibitory concentration (MIC) and maximum inhibitory dilution (MID) of 3 oral mouthrinses: Cepacol, Plax and Periogard. Seventy-seven complete denture wearers were randomly assigned into 2 groups, according to the product used for denture cleaning: Control group - conventional dentifrice (Kolynos-Super White); and Test group: experimental denture cleaning paste. Denture biofilm was collected at baseline and after 90 and 180 days after treatment by brushing the dentures with saline solution. After decimal serial dilution, samples were seeded onto agar sucrose bacitracin to count colonies with morphological characteristics of MS. MS identification was performed by the sugar fermentation tests. After this procedure, brain heart infusion broth (BHI) was added to oral mouthrinses (Plax, Cepacol e Periogard) and seeded on Petri dishes. The colonies were seeded using the Steers multiplier and, after the incubation, the MIC and MID of the mouthrinses were calculated. The results showed an incidence of $74.0 \%(n=57)$ of MS in the 77 complete dentures examined in the study, being $76.3 \%(n=29)$ of the Control group (conventional dentifrice) and 71.8\% (28) of the Test group (experimental denture cleaning paste). In both groups, the number of positive cases for MS decreased from day 0 to day 180. In the Test group there was a slight decrease in the incidence of Streptococcus mutans 90 days after use of the experimental denture cleaning paste, which was not observed in the Control group. As regards to mouthrinses, for both groups, Periogard showed antimicrobial action with the highest dilution, followed by Cepacol and Plax. In conclusion, the incidence of MS in complete dentures was high and Periogard was the mouthrinse with the strongest antimicrobial action against MS. The experimental denture cleaning paste showed a slight action against $S$. mutans after 90 days of treatment.
\end{abstract}

Key Words: denture, Streptococcus mutans, denture cleansers, biofilm.

\section{INTRODUCTION}

The oral health of elderly denture wearers is usually inadequate, and lesions associated with poor hygiene are a common occurrence $(1,2)$. This aspect emphasizes the denture wearers need to be aware of the care required for functional maintenance of the denture. Biofilm removal by means of adequate hygiene is of mandatory for denture wearers' oral health $(3,4)$.
Biofilm is a dense microbial layer formed by microorganisms and their metabolites (5). Mutans streptococci (MS) are microorganisms of great importance in biofilm formation. These microorganisms produce polysaccharides from sugar metabolism that have favor their adhesion and that of yeasts to the oral mucosa and denture surfaces (6).

MS are classified into sessile and planktonic types, with those that adhere to the surface being called 
sessile microbiota, and those who do not, referred to as planktonic microbiota. Studies have reported that the sessile microbiota is much more resistant to antimicrobial agents than the planktonic type $(7,8)$. This resistance is justified by the fact that the cell is sessile and when it fixes itself and develops, it is covered by a polysaccharide matrix that acts as a barrier against the diffusion of antimicrobial agents.

Adequate biofilm removal decreases proliferation of bacteria, such as MS and yeasts, which can cause halitosis (9), acrylic resin pigmentation and development of chronic atrophic candidiasis (10).

Mechanical and chemical methods are available for denture cleaning. Mechanical methods are classified into brushing (with water, soap, detergents or abrasives) and ultrasonic devices; the chemical methods use substances such as hypochlorites, peroxides, neutral peroxides with enzymes, enzymes, acids, crude drugs and dentures mouthrinses (11). Dentifrices are the most popular chemical denture cleansers. Common dentifrices are effective for biofilm removal; however because they are highly abrasive, they can create microporosities on the denture surfaces that may harbor microorganisms $(12,13)$.

There is great popular acceptance for mouthrinses, mainly due to their pleasant fragrance and fresh taste. Although their antimicrobial action against biofilm microorganisms has been well studied (14), no studies have been conducted clinically to test their effectiveness as denture cleanser.

The aims of this study were to evaluate the incidence of colony-forming units (cfu) of MS (sessile form) on denture before and after 90 and 180 days of use of an experimental denture cleaning paste, and to determine the minimum inhibitory concentration (MIC) and maximum inhibitory dilution (MID) of 3 mouthrinses: Cepacol (cetylpyridinium chloride), Plax (triclosan) and Periogard (chlorhexidine).

\section{MATERIAL AND METHODS}

Seventy-seven patients ( 29 men and 48 women) of the Complete Denture Clinic of the Ribeirão Preto Dental School, University of São Paulo, Brazil, were invited to participate in the study after approval by the Institutional Ethics Committee (Process \#2000.1.340.58.0) and signature of an informed consent form. The patients enrolled in the study wore complete maxillary dentures made of heat-activated acrylic resin without cracks and/ or relinings, and with wearing times between 6 months and 25 years.

\section{Cleaning Methods and Experimental Designs}

Patients were distributed into two groups, according to the treatment protocols: Control Group $(n=38)$ : subjects were provided with a conventional toothpaste recommended for cleaning natural teeth (Kolynos Super White; Kolynos do Brazil Ltda., São Bernardo do Campo, SP, Brazil); Test Group ( $\mathrm{n}=39$ ): subjects were given an experimental denture cleaning paste $(13,15,16)$. In both groups, soft-bristle brushes (Johnson \& Johnson Ltda., São Paulo, SP, Brazil) were supplied. All brushes had 28 bristles tufts, each bristle measuring $0.25 \mathrm{~mm}$ of diameter and $15.0 \mathrm{~mm}$ of height $(15,16)$.

On the first day of the experiment, each participant was provided with the pastes and brushes and given appropriate instructions on how to use them. The patients were instructed to brush the dentures 3 times a day: upon waking, after lunch and after dinner for a period of about 2 min per procedure. After brushing, patients were instructed to rinse the denture with tap water before reinserting it in the mouth. Patients were asked to remove the denture for sleeping, leaving it immersed in water.

All patients of both groups attended 3 visits: at baseline ( 0 day), 3 months ( 90 days) after treatment and 6 months (180 days) after treatment. Denture biofilm was collected at the 3 visits.

\section{Sample Collection Procedures}

Each maxillary complete denture was removed and placed on a sterile Petri dish $(20 \times 100 \mathrm{~mm})$ by the patient. The dentures were immediately rinsed with $10 \mathrm{~mL}$ of saline and the inner surfaces were brushed (Denture; Condor S.A., São Bento do Sul, SC, Brazil) for $5 \mathrm{~min}$. These procedures were carried out using 3 dental lamps placed in front of the operator to prevent sample contamination.

Sterile glass pearls were added to the test tube containing the resultant suspension, which was vortexed for $1 \mathrm{~min}$ and diluted in decimal series from $10^{0}$ to $10^{-5}$. Aliquots of $0.05 \mathrm{~mL}$ of the dilution were deposited on Petri plates containing the culture medium bacitracin sucrose agar/SB-20. The culture mediums were incubated at $37^{\circ} \mathrm{C}$ in candle jar for 48-72 h. After incubation, the plates were removed from the anaerobiosis jars, and examined 
by stereoscopic microscope (Binocular Stereoscopic SMZ645/660; Nikon, Japan) under reflected light.

\section{Isolation and Identification}

Three colonies with morphological characteristics of MS were transferred to the sodium thioglycolate medium and incubated at $37^{\circ} \mathrm{C}$ for $24 \mathrm{~h}$. They were then submitted to the identification test based on the scheme proposed by Shklair and Keene (17). Tests were performed, such as, for example, the tests for the fermentation of mannitol, sorbitol, raffinose, melibiose and the hydrolysis of esculin and arginine. The plates were incubated at $37^{\circ} \mathrm{C}$ for 20 to $30 \mathrm{~h}$.

\section{Determination of Minimum Inhibitory Concentration and Maximum Inhibitory Dilution}

The antiseptics were subjected to double dilution in sterile distilled water. After this, $19.0 \mathrm{~mL}$ of brain infusion agar (BHI) (Difco Laboratories Inc., Detroit, MI, USA) at $50^{\circ} \mathrm{C}$ were added, homogenized in the Mixer and seeded on previously coded Petri dishes $(20 \times 100 \mathrm{~mm})$. The colonies were seeded using the steers multiplier, similar the to biochemical identification procedure, from the highest to the lowest dilution. After 24 $\mathrm{h}$ of incubation, the minimum inhibitory concentration was considered to be the lowest concentration, and the maximum inhibitory dilution, the highest dilution that inhibited the development of strains.
Table 2. Presence of MS on dentures before and 90 and 180 days after the use of Kolynos Super white paste (Control group) and the experimental denture cleaning paste (Test group).

\begin{tabular}{rrrrrr}
\hline & \multicolumn{2}{c}{ Control group } & & \multicolumn{2}{c}{ Test group } \\
\cline { 2 - 3 } \cline { 5 - 6 } Days & $\begin{array}{c}\text { Dentures } \\
(\mathrm{n})\end{array}$ & $\begin{array}{c}\text { Positive MS cases } \\
\mathrm{n}(\%)\end{array}$ & & $\begin{array}{c}\text { Dentures } \\
(\mathrm{n})\end{array}$ & $\begin{array}{c}\text { Positive MS cases } \\
\mathrm{n}(\%)\end{array}$ \\
\hline 0 & 38 & $29(76.3)$ & & 39 & $28(71.8)$ \\
90 & 31 & $23(74.2)$ & & 36 & $23(63.9)$ \\
180 & 28 & $20(71.4)$ & & 28 & $21(75.0)$ \\
\hline
\end{tabular}

Table 3. Prevalence of S. mutans on the dentures before and 90 and 180 days after use of Kolynos Super white paste (Control group) and the experimental denture cleaning paste (Test group).

\begin{tabular}{|c|c|c|c|c|c|c|}
\hline \multirow{3}{*}{ Days } & \multicolumn{3}{|c|}{ Control group } & \multicolumn{3}{|c|}{ Test group } \\
\hline & \multirow{2}{*}{$\begin{array}{l}\text { Positive } \\
\text { MS cases }\end{array}$} & S. mutans & $\begin{array}{l}\text { S. mutans }+ \\
\text { S. sobrinus }\end{array}$ & \multirow{2}{*}{$\begin{array}{l}\text { Positive } \\
\text { MS cases }\end{array}$} & S. mutans & $\begin{array}{l}\text { S. mutans + } \\
\text { S. sobrinus }\end{array}$ \\
\hline & & $\mathrm{n}(\%)$ & $\mathrm{n}(\%)$ & & $\mathrm{n}(\%)$ & $\mathrm{n}(\%)$ \\
\hline 0 & 29 & $20(69.0)$ & $9(31.0)$ & 28 & $23(82.1)$ & $5(17.9)$ \\
\hline 90 & 23 & $20(87.0)$ & $3(13.0)$ & 23 & $19(82.6)$ & 4 (17.4) \\
\hline 180 & 20 & $14(70.0)$ & $6(30.0)$ & 21 & $16(76.2)$ & $5(23.8)$ \\
\hline
\end{tabular}


the majority of dentures were harbored only S. mutans (monocolonized), but some of them harbored S. mutans and S. sobrinus (multicolonized).

Table 4 shows the MIC of the mouthrinses calculated on the basis of the percentage of active ingredient described on the label. It can be observed, for both groups, that the strains isolated before the use of the solutions were more resistant than those isolated after use. With regard to the MID, Table 5 shows that, after the use of the respective agents for 90 days, there was an increase in values against all antiseptics and these results did not change after 180 days.

\section{DISCUSSION}

Denture biofilm is defined as an intimate association of microorganisms surrounded by metabolites and salivary components $(16,18)$. Among these microorganisms, MS are outstanding, as they initiate the formation of biofilm and facilitate the adhesion of yeasts to the mucosa and dentures. Poor denture hygiene is therefore a major factor predisposing the patient to the development of denture stomatitis, since it allows biofilm accumulation. Proper hygiene is mandatory to maintain the oral health of denture wearers.

Table 4. Minimum inhibitory concentration of the mouthrinses (in $\mu \mathrm{g} / \mathrm{mL}$ ) against the MS strains isolated before and 90 and 180 days after use of Kolynos Super white paste (Control group) and the experimental denture cleaning paste (Test group).

\begin{tabular}{|c|c|c|c|c|c|c|}
\hline \multirow{2}{*}{ Days } & \multicolumn{3}{|c|}{ Control } & \multicolumn{3}{|c|}{ Experimental } \\
\hline & Cepacol & Plax & Periogard & Cepacol & Plax & Periogard \\
\hline 0 & 12.50 & 15.00 & 7.50 & 12.50 & 15.00 & 7.50 \\
\hline 90 & 3.125 & 1.875 & 3.75 & 6.25 & 1.875 & 3.75 \\
\hline 180 & 3.125 & 1.875 & 3.75 & 6.25 & 1.875 & 3.75 \\
\hline
\end{tabular}

Table 5. Maximum inhibitory dilution of the mouthrinses (in $\mu \mathrm{g} / \mathrm{mL}$ ) against the MS strains isolated before and 90 and 180 days after use of Kolynos Super white paste (Control group) and the experimental denture cleaning paste (Test group).

\begin{tabular}{rccccccc}
\hline \multirow{2}{*}{ Days } & \multicolumn{3}{c}{ Control } & & \multicolumn{3}{c}{ Experimental } \\
\cline { 2 - 3 } \cline { 7 - 8 } \cline { 7 - 8 } & Cepacol & Plax & Periogard & & Cepacol & Plax & Periogard \\
\hline 0 & 40 & 20 & 160 & & 40 & 20 & 160 \\
90 & 320 & 160 & 320 & & 160 & 160 & 320 \\
180 & 320 & 160 & 320 & & 160 & 160 & 320 \\
\hline
\end{tabular}

In the present study, MS were identified in $74 \%$ of the complete dentures, i.e., 57 out of 77 . Of these, $75.4 \%$ were monocolonized by the $S$. mutans and $24.6 \%$ were multicolonized by the $S$. mutans and $S$. sobrinus (Table 1). These values are close to those of Carlsson et al. (19), who collected biofilm samples from the complete dentures of 20 patients, and found S. mutans in $14(70 \%)$ patients. Monroy et al. (5) found S. mutans in $49.5 \%$ of the dentures examined.

Previous studies evaluated the efficacy of alkaline peroxide against $S$. mutans biofilm $(20,21)$. However, as regards to toothpastes, the results have not been widely reported. In the Test group, there was a slight decrease in the incidence of $S$. mutans 90 days after use of the experimental denture cleaning paste, which was not observed in the Control group (Table 3). This observation is consistent with a previous clinical study (22) that evaluated the antimicrobial activity of two experimental dentifrices (D1 and D2) against MS present on dentures, and found that both dentifrices decreased biofilm coverage compared to the control group. D1 was very effective in reducing MS, while D2 showed intermediate results.

As regards the results achieved after 180 days of the treatments (Tables 2 and 3), a return of the incidence of MS could be observed in the Test group and a slight decrease in the incidence of these microorganisms in the Control group.

The results with respect to the MIC (Table 4) of Periogard $(7.5 \mu \mathrm{g} /$ $\mathrm{mL}$ ) are consistent with those of Ashley (23) and different from those of Grönroos et al. (24). Ashley (23) evaluated the antimicrobial action of a mouthwash based on chlorhexidine (Corsodyl) against MS and found MIC of $8.0 \mu \mathrm{g} / \mathrm{mL}$. Grönroos et al. (24) found that chlorhexidine presented antimicrobial activity against MS at even lower concentrations (1.0 to 2.0 
$\mathrm{mg} / \mathrm{mL}$ ). Probably, the conflicting results are due to the different methodologies used, although both studies were conducted in vivo. Gröonros et al. (24) evaluated the effect of chlorhexidine on MS in young dentate mothers whereas the present study evaluated the action of chlorhexidine against these microorganisms present on complete dentures. In addition, in the study by Gröonros et al. (24), the participants brushed their teeth periodically with a gel containing $0.3 \%$ chlorhexidine digluconate and $0.2 \% \mathrm{NaF}$, whereas in this study, $0.12 \%$ chlorhexidine was used as a soaking solution for dentures.

With regard to the MID (Table 5), all mouthrinses showed the capacity of inhibiting MS at the lowest dilution (1:20). Albuquerque Junior et al. (25) also determined the MID of $0.12 \%$ chlorhexidine (Periogard) and $0.05 \%$ cetylpyridinium chloride (Cepacol), as well as the effect of $0.12 \%$ chlorhexidine (Periogard) on the salivary counts of S. aureus and MS. Saliva samples from 60 patients were collected before and after use of mouthrinses and cultured in appropriate media. The results showed that after rinsing with chlorhexidine, the reductions in the cfu were above $99 \%$ for all the studied microorganisms. All isolates were inhibited with 1:20 and 1:80 dilutions of cetylpyridinium chloride and chlorhexidine, respectively. The authors concluded that chlorhexidine mouthrinse is effective in reducing salivary microorganisms to levels currently considered safe, and it is still effective in a 1:80 dilution.

Given these facts, it is clear that there is a need for further clinical studies to assess the MIC and MID of mouthwashes against sessile strains of MS, so that, an evidence-based denture disinfection protocol could be established, in which mouthwashing is used as an auxiliary method to brushing with toothpaste.

Based on the results of this study, it can be concluded that there is high incidence of MS on complete dentures, and thus denture wearers can act as sources mutans infection and transmission. Periogard had the most effective antimicrobial activity, followed by Cepacol and Plax, and may be used as an auxiliary agent in maintaining the oral hygiene of denture wearers. The experimental denture cleaning paste showed a slight action against $S$. mutans after 90 days use.

\section{RESUMO}

O objetivo deste estudo foi avaliar a incidência de estreptococos do grupo mutans (forma séssil) de próteses totais superiores após o uso de uma pasta específica para higienização de próteses totais, bem como determinar a concentração inibitória mínima (CIM) e diluição inibitória máxima (DIM) de 3 enxaguatórios bucais: Cepacol, Plax e Periogard. Setenta e sete usuários de próteses totais foram distribuídos em 2 grupos: (A) grupo Controle: dentifrício convencional (Kolynos Super Branco) e (B) grupo Teste: pasta experimental para higiene de próteses (1). O biofilme das próteses foi coletado no início e após 90 e 180 dias dos tratamentos, por meio de escovação das próteses com solução salina. Após a diluição decimal seriada, as amostras foram semeadas em agar sacarose bacitracina para a contagem de colônias características de estreptococos do grupo mutans. A identificação dos estreptococos do grupo mutans foi realizada por meio de testes de fermentação de açúcares. Após este procedimento, o caldo de infusão de cérebro e coração (BHI) foi adicionado aos antissépticos (Plax, Cepacol e Periogard) e semeado em placas de Petri. As colônias foram semeadas usando o mutiplicador de Steers e após a incubação, a concentração inibitória mínima e a concentração inibitória máxima dos enxaguatórios foram calculadas. Os resultados mostraram que a incidência de estreptococos do grupo mutans nas 77 próteses totais examinadas foi de $74,0 \%(n=57)$, sendo $76,3 \%(\mathrm{n}=29)$ do grupo Controle (pasta convencional) e 71,8\% $(\mathrm{n}=28)$ do grupo Teste (pasta experimental). Em ambos os grupos, o número de casos positivos para estreptococos do grupo mutans diminuiu, do início (0 dias) para 180 dias. Houve uma pequena diminuição da incidência de Streptococcus mutans após 90 dias do uso da pasta experimental, o que não foi observado no grupo controle. Com relação aos enxaguatórios, para ambos os grupos, o Periogard apresentou atividade antimicrobiana com diluições maiores, seguido do Cepacol e Plax. Pôde-se concluir que a incidência de estreptococos do grupo mutans em próteses totais foi elevada e que o Periogard foi o enxaguatório com melhor ação antimicrobiana contra os estreptococos do grupo mutans. A pasta experimental mostrou uma pequena ação contra $S$. mutans após 90 dias de tratamento.

\section{ACKNOWLEDGEMENTS}

This research was supported by the Institutional Program for Scientific Initiation Scholarships PIBIC/CNPq (Grant \#80.30.70/87.0).

\section{REFERENCES}

1. Peracini A, Andrade IM, Paranhos H de F, Silva CH, de Souza RF. Behaviors and hygiene habits of complete denture wearers. Braz Dent J 2010;21:247-252.

2. Marchini L, Vieira PC, Bossan TP, Montenegro FL, Cunha VP. Self-reported oral hygiene habits among institutionalized elderly and their relationship to the condition of oral tissues in Taubaté, Brazil. Gerodontology 2006;23:33-37.

3. Shay K. Denture hygiene: a review an update. J Contemp Dent Pract 2000;1:1-8.

4. Pires FR, Santos EB, Bonan PR, De Almeida OP, Lopes MA. Denture stomatitis and salivary Candida in Brazilian edentulous patients. J Oral Reabil 2002; 29:1115-1119.

5. Nikawa H, Hamada T, Yamamoto T. Denture plaque-past and recent concerns. J Dent 1998;26:299-304.

6. Monroy TB, Maldonado VM, Martínez FF, Barrios BA, Quindós G, Vargas LOS. Candida albicans, Staphylococcus aureus and Streptococcus mutans colonization in patients wearing dental 
prostheses. Med Oral Patol Oral Cir Bucal 2005;10:27-39.

7. Jacquelin LF, Carquin T, Le Magres E. Comparison de l'activité dún antiseptique à base de chlorhexidine sur Streptococcus mutans en suspensión et en biofilm. Path Biol 1992;40:1992.

8. Ramirez de Arellano E, Pascual A, Martinez-Martinez L, Perea EJ. Activity of eight antibacterial agents on Staphylococcus epidermidis attached to Teflon catheters. J Med Microbiol 1994:40:43-47.

9. Verran J, Whitehead K. Factors affecting microbial adhesion to stainless steel and other materials used in medical devices. Int J Artif Organs 2005;183:69-72.

10. Akpan A, Morgan R. Oral candidiasis - Review. Postgrad Med J 2002;78:455-459.

11. Nikawa H, Hamada T, Yamashiro H, Kumagai H. A review of in vitro and in vivo methods to evaluate the efficacy of denture cleansers. Int J Prosthodont 1999;12:153-159.

12. Freitas-Pontes KM, Silva-Lovato CH, Paranhos HFO. Weight loss of four commercially available heat-polymerized acrylic resins after toothbrushing with three different dentifrices. J Appl Oral Sci 2009;17:116-121.

13. Pisani MX, Bruhn JP, Paranhos HF, Silva-Lovato CH, de Souza RF, Panzeri H. Evaluation of the abrasiveness of dentifrices for complete dentures. J Prosthodont 2010;19:369-373.

14. Uludamar A, Kulak-Ozkan Y, Kadir T, Ceyhan I. In vivo efficacy of alkaline peroxide tablets and mouthwashes on Candida albicans in patients with denture stomatitis. J Appl Oral Sci 2010;18:291-296.

15. Paranhos HFO, Panzeri H, Lara EHG, Candido RC, Ito IY Capacity of denture plaque removal and antimicrobial action of a specific paste formulated for denture cleaning. Braz Dent $\mathrm{J}$ 2000;11:21-25.

16. Andrucioli MCD, Macedo LD, Panzeri H, Lara EHG, Paranhos HFO. Comparison of two cleansing pastes for the removal of biofilm from dentures and palatal lesions in patients with atrophic chronic candidiasis. Braz Dent J 2004;15:220-224.

17. Shklair IL, Keene HJ. A biochemical scheme for the separation of the five varieties of Streptococcus mutans. Arch Oral Biol
1974;19:1079-1081.

18. Baehni PC, Takeuchi Y. Anti-plaque agents in the prevention of biofilm-associated oral diseases. Oral Dis 2003;9:23-29.

19. Carlsson J, Söderholm G, Almfeldt I. Prevalence of Streptococcus sanguis and Streptococcus mutans in the mouth of persons wearing full-dentures. Arch Oral Biol 1969;14:243-249.

20. Paranhos HFO, Silva-Lovato CH, Souza RF, Cruz PC, FreitasPontes KM, Watanabe E, Ito IY. Effect of three methods for cleaning dentures on biofilms formed in vitro on acrylic resin. J Prosthodont 2009; 18:427-431.

21. Andrade IM, Cruz PC, Silva CH, Souza RF, Paranhos HFO, Candido RC, Marin JM, Souza-Gugelmin MCM. Effervescent tablets and ultrasonic devices against Candida and mutans streptococci in denture biofilm. Gerodontology 2010 [DOI: 10.1111/j.1741-2358.2010.00378.x. Epub ahead of print].

22. Panzeri H, Lara EHG, Paranhos HFO, Silva CHL, Souza RF, Souza-Gugelmin MCM, et al.. In vitro and clinical evaluation of specific dentifrices for complete denture hygiene. Gerodontology 2009;26:26-33

23. Ashley KC. The antimicrobial properties of two commonly used antiseptic mouthwashes - Corsodyl and oraldene. J Appl Bacteriol 1984;56:21-25

24. Grönroos L, Mättö J, Saarela M, Luoma AR, Luoma H, Jousimies-Somer $\mathrm{H}$, et al.. Chlorhexidine susceptibilities of mutans streptococci serotypes and ribotypes. Antimicrob Agents Chemother 1995;39:894-898.

25. Albuquerque Jr RF, Head TW, Mian H, Rodrigo A, Muller K, Sanches K, et al.. Reduction of salivary S. aureus and mutans group streptococci by a preprocedural chlorhexidine rinse and maximal inhibitory dilutions of chlorhexidine and cetylpyridinium. Quintessence Int 2004;35:635-640.

Accepted December 21, 2010 